\title{
SINGLE INDEX MODEL SEBAGAI ALAT ANALISIS OPTIMALISASI PORTOFOLIO INVESTASI SAHAM \\ (Studi Kasus pada Kelompok Saham LQ-45 di BEI Tahun 2009-2011)
}

\author{
Sigit Triharjono \\ Mahasiswa Magister Manajemen Bisnis \\ Sekolah Pasca Sarjana Universitas Pendidikan Indonesia
}

\begin{abstract}
Abstrak
Penelitian ini bertujuan 1) Untuk menentukan sekelompok saham LQ-45 untuk dibentuk menjadi portofolio yang optimal dengan menggunakan single index model. 2) Untuk membuktikan bahwa mendiversikasikan sekelompok saham-saham dalam satu portofolio investasi saham akan menurunkan risiko lebih kecil daripada risiko saham-saham tersebut apabila ditransaksikan secara individual. Teknik pengambilan sampel penelitian ini menggunakan metode sampling purposive. Teknik pengumpulan data penelitian ini menggunakan cara dokumentasi dengan data sekunder. Metode analisis data yang digunakan dalam penelitian ini adalah Single Index Model. Hasil penelitian menunjukkan 1) Dengan menggunakan Single Index Model diperoleh hasil portofolio optimal dan perusahaan yang termasuk kedalam portofolio optimal adalah saham perusahaan Astra Argo Lestari,Tbk (AALI) dan Aneka Tambang, Tbk (ANTM). 2) Terbukti bahwa dengan diversifikasi dalam suatu portofolio saham dapat menurunkan risiko daripada risiko saham-saham pembentuk portofolio apabila ditransaksikan secara individual.
\end{abstract}

Kata Kunci: Optimalisasi, Portofolio Saham, Single Index Model, LQ-45.

\section{PENDAHULUAN}

Fungsi indeks harga saham, pertama indeks harga saham dibuat agar dapat menjadi indikator keuntungan bagi pemodal. Kedua, sebagai fasilitas pembentukan portofolio pasif. Ketiga, sebagai alat untuk menghitung risiko sistematik, yakni risiko yang tidak dapat dimitigasi melalui manajemen risiko, termasuk diversifikas. Risiko seperti ini dilihat dari seberapa besar perubahan harga sebuah efek menyimpang dari perubahan harga saham secara keseluruhan. Keempat, sebagai sarana mencari peluang investasi. Kelima, untuk melihat perkembangan ekonomi. Keenam, sarana mengembangkan produk instrumen investasi derivatif.

Indeks yang digunakan di BEI sebagai dasar pembentukan portofolio saham adalah IHSG, indeks liquid (ILQ 45), Jakarta Islamic Index (JII), Indeks Papan Utama dan Papan Pengembangan, dan Indeks Kompas 100 pada BEI (Jogiyanto, 2010:101). Dikutip dari www.bukumarketiva.we.id mengungkapkan bahwa "Indeks saham paling terkenal yang ada di BEI adalah IHSG (Indeks Harga Saham Gabungan) dan LQ45 (Liquidity 45)". Namun penggunaan IHSG sebagai proksi penghitung return pasar dirasakan masih memiliki kelemahan, karena IHSG menggunakan pembobotan berdasarkan atas kapitalisasi seluruh saham. Sehingga IHSG hanya mencerminkan pergerakan saham-saham aktif dan likuid di pasar sekunder dan sahamsaham yang kurang aktif tidak terlihat pergerakannya. Sedangkan saham-saham LQ 45 merupakan saham likuid berkapitalisasi pasar yang tinggi, memiliki frekuensi perdagangan tinggi, memiliki prospek pertumbuhan serta kondisi keuangan yang cukup baik, tidak fluktuatif dan secara obyektif telah diseleksi oleh BEI dan merupakan saham yang aman dimiliki karena fundamental kinerja saham tersebut bagus, sehingga dari sisi risiko kelompok saham LQ 45 memiliki risiko terendah dibandingkan saham-saham lain. Fluktuatif harga pada 
kelompok saham LQ 45 cenderung smooth yang menjadikan return dari capital gain tidak setinggi pada kelompok saham yang mengalami fluktuasi harga siginifikan. Karakteristik saham LQ 45 ini dapat mewakili kinerja portofolio saham, di mana penilaian kinerja portofolio dilihat dari dua sisi yaitu imbal hasil dan risiko

return pasar yang dilihat dari return ILQ 45 mengalami penurunan dari tahun 2009-2011, penurunan sebesar 0.0252 (dalam satuan rasio) di tahun 2010 dari tahun sebelumnya sebesar 0.0552 (dalam satuan rasio) di tahun 2009 atau penurunan sebesar 0.0032 (dalam satuan rasio) di tahun 2011 dari tahun sebelumnya sebesar 0.0252 (dalam satuan rasio) di tahun 2010, penurunan dari tahun ke tahun yang disebabkan oleh dampak dari krisis ekonomi global pada tahun 2008 ditambah lagi krisis ekonomi Eropa tahun 2011. Hal ini mengindikasikan bahwa terdapat unsur risiko dalam investasi tersebut. Meskipun saham-saham LQ 45 merupakan sekumpulan saham yang berkapitalisasi pasar tinggi dan memiliki likuiditas tinggi namun tidak lepas dari ketidakpastian akan tingkat pengembalian yang akan diterima investor sehingga kalangan investor tetap perlu mempertimbangkan berbagai ketidakpastian yang mungkin terjadi dan mengantisipasinya.

Fenomena di atas mendorong ilmuwan dan pakar praktisi investasi untuk terus-menerus mengembangkan cara yang lebih baik agar suatu harapan terhadap imbal hasil dan penghindaran risiko pilihan keputusan investasi benar-benar optimal dalam arti pada tingkat imbal hasil tertentu dapat terpilih keputusan investasi yang memberikan risiko minimal atau pada tingkat risiko tertentu terpilih keputusan investasi yang memberikan tingkat imbal hasil maksimal. Berbagai variasi dan kombinasi pendekatannya dapat meliputi analisis yang bersifat fundamental-tehnikal, internal-eksternal, mikromakro, risiko sistematis-tidak sistematis, kualitatif-kuantitatif, investasi tunggal-investasi majemuk (portofolio), dan prilaku rasional-tidak rasional dari investor, dan lain sebagainya yang bersama-sama membentuk suatu kerangka konseptual maupun praktis dalam menentukan tujuan dari optimalisasi keputusan investasi.

Saham-saham biasanya bergerak searah dengan indeks pasar. Fenomena yang terjadi di kalangan para investor adalah biasanya investor dalam melakukan keputusan transaksinya berdasarkan pergerakan indeks namun tetap bila dilakukan atas dasar transaksi tunggal, maka risikonya tetap tinggi, maka salah satu cara untuk menekan risiko adalah dengan diversifikasi.

Diversifikasi risiko ini sangat penting bagi investor, karena dapat meminimumkan risiko tanpa harus mengurangi return yang diterima. Investor dapat melakukan diversifikasi dengan beberapa cara, seperti misalnya dengan membentuk portofolio berisi banyak aktiva, membentuk portofolio secara random atau diversifikasi secara metode markowitz (Jogiyanto, 2010:279). Diversifikasi dengan banyak aktiva berasumsi bahwa rate of return untuk masing-masing sekuritas secara statistik adalah independen tapi kenyataanya asumsi ini untuk masing-masing sekuritas adalah kurang realistis, karena umumnya return sekuritas berkorelasi satu dengan yang lainnya. Diversifikasi secara random merupakan pembentukan portofolio secara acak tanpa memperhatikan karakteristik investasi yang relevan seperti return sekuritas itu sendiri. Diversifikasi secara markowitz ditunjukan dengan mean-variance dari markowitz, sekuritassekuritas yang mempunyai korelasi +1 akan menurunkan portofolio.

Sejak Harry Markowitz mengemukakan teori portofolio modern pada tahun 1952, risiko investasi dapat diperkecil melalui pembentukan portofolio yang efisien, sehingga risikonya lebih rendah daripada risiko masing-masing intrumen investasi (misalnya saham) yang membentuk portofolio tersebut (Zalmi Zubir, 2011:19). Masalah yang terjadi dalam membentuk portofolio adalah terdapat banyak sekali kemungkinan portofolio yang dapat dibentuk dari kombinasi aktiva berisiko yang tersedia di 
pasar. Kombinasi ini dapat mencapai jumlah yang tidak terbatas, maka muncul pertanyaan portofolio mana yang akan dipilih oleh investor Jika investor adalah rasional maka mereka akan memilih portofolio yang optimal (Jogiyanto, 2010:285).

Portofolio optimal dapat ditentukan dengan menggunakan model Markowitz atau dengan single index model.. Penelitian ini tidak terkecuali didasarkan pada pendekatan-pendekatan tersebut di atas dalam memandang fenomenafenomena di dunia investasi khususnya di Indonesia yang menjadi alasan penulisannya. Proses berfikirnya diawali dengan pertanyaan, pertama apakah tiori-tiori dasar maupun turunan yang telah dirumuskan oleh para pakar ilmu investasi dalam mengkaji tujuan-tujuan keputusan investasi? Kedua, sejauh mana penelitian-penelitian telah dilakukan sebelumnya mengenai bidang investasi ini? Ketiga bagaimana tiori dan hasil-hasil penelitian pada bidang investasi ini memberikan nilai tambah dalam pengembangan dunia praktisnya? Keempat adalah apa hasil-hasil tersebut dapat berlaku pula pada realita situasi, kondisi, waktu, dan obyek yang berbeda? Pertanyaan-pertanyaan tersebut di atas kemudian dipersempit untuk membatasi ruang lingkup penelitian yang diarahkan pada penerapan salah satu metode kuantitatif yang sudah sejak lama dirumuskan oleh William Sharpe (1963) dalam menentukan suatu keputusan investasi optimal secara majemuk (portofolio) yaitu model indeks tunggal (singel index model).

Alasan pengambilan model indeks tunggal sebagai kajian penelitian adalah pertama model ini merupakan penyederhanaan dari modelmodel optimalisasi portofolio investasi lain seperti Model Markowitz dan Capital Asset Pricing Model (CAPM). Kedua adalah makin meluasnya pemakaian indeks produk investasi sebagai panduan investasi yang luas digunakan oleh investor dalam menentukan keputusan investasi mereka seperti Indeks Harga Saham Gabungan (IHSG) dan Indeks LQ-45 yang ada di
Indonesia. Ketiga adalah tiori mengenai kaitan pergerakan harga saham dengan indeks pasar, seperti yang dikemukan oleh Jogiyanto (2010:339) bahwa "model indeks tunggal didasarkan pada pengamatan bahwa harga dari kebanyakan saham cenderung mengalami kenaikan harga jika indeks harga saham naik. Kebalikannya juga benar, yaitu jika indeks harga saham turun, kebanyakan saham mengalami penurunan harga." Alasan keempat adalah adanya beberapa penelitian di Indonesia yang telah lebih dahulu meneliti tentang penerapan model indeks tunggal ini dalam beberapa obyek penelitian.

Noki Rachmanto (2002) meneliti tentang analisis pembentukan portofolio optimal saham menggunakan metode single index model di Bursa Efek Jakarta tahun 1998-2000. Beliau menemukan bahwa saham-saham yang masuk kandidat dengan saham-saham yang tidak masuk kandidat menunjukkan perbedaan yang signifikan, sedangkan risiko yang diukur dengan varians tidak menunjukkan perbedaan yang berarti.

Sukarno (2007) meneliti tentang analisis pembentukan portofolio optimal saham menggunakan metode single index model di Bursa Efek Jakarta pada tahun 2003-2006 dengan hasil penelitiannya yaitu terdapat perbedaan yang signifikan antara return 14 saham kandidat dengan return 19 saham non kandidat portofolio. Rata-rata return saham kandidat lebih tinggi $(24,43)$ dibandingkan ratarata return saham non kandidat $(11,53)$. Jadi portofolio optimal dalam penelitian ini dibentuk oleh saham yang mempunyai return tertinggi pada tingkat risiko yang relatif sama.

Robi (2008) meneliti tentang analisis portofolio optimal saham-saham LQ-45 periode 2005 dan 2006 dengan metode single index model di Bursa Efek Jakarta. Beliau menemukan bahwa return yangdi dapat antara berinvestasi pada saham secara individual dengan berinvestasi dengan membentuk portofolio, ada saham yang secara individual menghasilkan 
return yang lebih besar daripada return portofolio, namun risiko yang ditanggung lebih besar daripada risiko portofolio. Dalam hal ini kita dapat melihat bahwa tidak ada saham yang return-nya lebih besar daripada portofolio namun risiko yang ditanggung lebih kecil daripada portofolio. Oleh karena itu terbukti bahwa dengan membentuk portofolio kita dapat melakukan diversifikasi atau pengurangan risiko.

Viola Claudia (2011) meneliti tentang analisis portofolio optimal saham-saham LQ-45 periode 2009-2011 di Bursa Efek Indonesia dengan menggunakan model indeks tunggal. Beliau menemukan bahwa terdapat saham yang secara individual menghasilkan return yang lebih besar daripada return portofolio, tetapi semakin besar return yang di peroleh maka risiko yang ditanggung lebih besar daripada risiko portofolio. Dalam hal ini, dapat di lihat bahwa tidak ada saham yang return- nya lebih besar daripada return saham yang di bentuk melalui portofolio tetapi yang dapat di tekankan dalam hal ini adalah risiko yang ditanggung lebih kecil jika investor berinvestasi pada masing-masing sekuritas. Oleh karena itu, terbukti bahwa dengan membentuk portofolio optimal kita dapat melakukan diversifikasi atau pengurangan risiko.

Arif dan Didin (2011) meneliti tentang pembentukan portofolio optimal saham dengan model indeks tunggal pada saham-saham perbankan di Bursa Efek Indonesia tahun 2011. Beliau menemukan bahwa risiko yang diperoleh setelah pembentukan portofolio optimal ini lebih kecil dibandingkan dengan berinvestasi dengan saham individual.

\section{KERANGKA PEMIKIRAN}

Kegiatan investasi telah memberikan kontribusi yang besar dalam mendorong kinerja laju pertumbuhan ekonomi modern saat ini. Pasar modal sebagai salah satu penggerak dari laju pertumbuhan ekonomi modern memberi peran yang sangat penting, penurunan rata-rata index di pasar modal dunia tahun 2008 bisa disebabkan oleh adanya fenomena krisis keuangan global ataupun faktor lainnya, pada tahun 2008 kegiatan investasi menurun, ratarata index yang mencerminkan pergerakan pasar modal menurun secara drastis, tetapi seiring berjalannya waktu pergerakan pasar modal kembali naik di tahun berikutnya tetapi menurun lagi di tahun 2011, penurunan ini disebabkan oleh krisis ekonomi Eropa, krisis ini dipicu oleh adanya krisis utang Yunani yang mulai dirasakan akhir 2009 semakin berkembang dan menjalar ke Irlandia dan Portugal, krisis utang ketiga negara tersebut memicu pergolakan di bursa saham Eropa dimana saham bank-bank Eropa mengalami penurunan yang tajam, krisis ekonomi ini kemudian menjalar kembali ke Itali, Spanyol, Inggris, dan Perancis pada tahun 2011. Jadi, fenomena yang terjadi di tahun 2008 dan tahun 2011 memberikan dampak pada pergerakan pasar modal dunia, dampak ini pula apakah dirasakan oleh perdagangan pasar saham di BEl

Peran Bursa khususnya BEl sangat penting sekali selain dilihat dari fungsi bursa efek itu sebagai fasilitator, mengupayakan likuiditas instrument, transparansi dan lainnya, BEI memberikan kontribusi positif bagi pertumbuhan perekonomian Indonesia. Investasi mencapai tingkat yang tinggi dan menjadi sangat berbeda pada saat-saat lainnya. Hal ini dapat dimungkinkan karena besarnya tingkat investsi yang sangat bergantung kepada besarnya harapan yang akan dicapai di masa yang akan datang. Apabila ramalan di masa akan datang prospektif, maka ada kecenderungan para investor akan melakukan lebih banyak investasi, dan begitu pula sebaliknya, seperti diketahui bahwa investasi akan menciptakan pertambahan dalam pendapatan nasional. Investasi pada tahap awal melalui mulplier effect akan menyebabkan permintaan produktif masyarakat meningkat, hal ini akan mendorong tumbuhnya jenis investasi lain 
Saham merupakan salah satu instrumen investasi yang paling menarik karena memiliki mobilitas yang tinggi. Memang risiko menanamkan uang pada pasar saham lebih besar, tetapi masih dapat diminimalisir, dengan cara melihat saham-saham perusahaan yang berkinerja baik, atau yang memiliki fundamental yang baik, setelah itu baru kita memilih sahamsaham yang memang memiliki peluang pada situasi ekonomi saat ini, para pelaku bursa khususnya investor perlu memerlukan parameter dalam menginvestasikan dana yang akan ditanamkannya pada saham, salah satu parameter untuk melihat pergerakan harga saham adalah indeks harga saham.

Penggunaan IHSG sebagai proksi penghitung return pasar dirasakan memiliki kelemahan, karena IHSG menggunakan pembobotan berdasarkan atas kapitalisasi seluruh saham. Sehingga IHSG hanya mencerminkan pergerakan saham-saham aktif dan likuid di pasar sekunder dan saham-saham yang kurang aktif tidak terlihat pergerakannya. Sedangkan saham-saham LQ 45 merupakan saham likuid kapitalisasi pasar yang tinggi, memiliki frekuensi perdagangan tinggi, memiliki prospek pertumbuhan serta kondisi keuangan yang cukup baik, tidak fluktuatif dan secara obyektif telah diseleksi oleh BEI dan merupakan saham yang aman dimiliki karena fundamental kinerja saham tersebut bagus, sehingga dari sisi risiko kelompok saham LQ 45 memiliki risiko terendah dibandingkan sahamsaham lain. Fluktuatif harga pada kelompok saham LQ 45 cenderung smooth menjadikan return dari capital gain tidak setinggi pada kelompok saham yang mengalami fluktuasi harga siginifikan. Karakteristik saham LQ 45 ini dapat mewakili kinerja portofolio saham, dimana penilaian kinerja portofolio dilihat dar dua sisi yaitu hasil dan risiko, walaupun begitu masih terdapat ketidakpastian terhadap return yang diterima oleh investor

Salah satu cara untuk menekan risiko adalah dengan diversifikasi. Diversifikasi risiko ini sangat penting bagi investor, karena dapat meminimumkan risiko tanpa harus mengurangi return yang diterima. Investor dapat melakukan diversifikasi dengan beberapa cara, seperti misalnya dengan membentuk portofolio berisi banyak aktiva, membentuk portofolio secara random atau diversifikasi secara metode markowitz.

Harry Markowitz mengemukakan teori portofolio modern pada tahun 1952, risiko investasi dapat diperkecil melalui pembentukan portofolio yang efisien, sehingga risikonya lebih rendah daripada risiko masing-masing intrumen investasi (misalnya saham) yang membentuk portofolio tersebut). Dalam membentuk portofolio adalah terdapat banyak sekali kemungkinan portofolio yang dapat dibentuk dari kombinasi aktiva berisiko yang tersedia di pasar, kombinasi ini dapat mencapai jumlah yang tidak terbatas, maka muncul pertanyaan portofolio mana yang akan dipilih oleh investor, jika investor adalah rasional maka mereka akan memilih portofolio yang optimal.

Portofolio optimal dapat ditentukan dengan menggunakan model Markowitz atau dengan single index model. Salah satu teknik analisa portofolio optimal yang dilakukan oleh Elton dan Gruber (1995) adalah menggunakan single indeks model. Single indeks model digunakan untuk menyederhanakan perhitungan model Markowitz dalam menganalisis portofolio optimal, selain itu portofolio saham pada dasarnya merupakan bentuk investasi jangka pendek bagi investor sehingga dalam penyusunannya memerlukan analisis jangka pendek pula.

\section{METODE PENELITIAN}

Populasi dari penelitian ini adalah perusahaan yang termasuk dalam kategori Indeks LQ 45 pada periode 2009-2011. Sampel yang digunakan dalam penelitian ini dengan menggunakan teknik sampling purposive. Menurut Sugiyono (2011:85), sampling purposive adalah teknik penentuan sampel 
dengan pertimbangan tertentu. Berdasarkan kriteria yang telah ditetapkan terdapat 7 perusahaan yang dapat dijadikan sampel penelitian diantaranya : PT Astra Agro Lestari Tbk (AALI), PT Indofood CBP Sukses Makmur Tbk (ICBP), PT Bank Mandiri (BMRI), PT Indomobil Sukses Internasional Tbk (IMAS), PT Aneka Tambang Tbk (ANTM), PT Alam Sutera Realty Tbk (ASRI), PT Astra International Tbk (ASII).Penelitian ini dilakukan dengan menggunakan metode deskriptif. Variabel yang digunakan adalah Return aktiva bebas risiko (RBR), Expected return saham individual $E(R i)$, Beta, Variance, ERB, Ci, Proporsi dana masing-masing portofolio. Teknik pengumpulan data dalam penelitian ini adalah metode dokumentasi yaitu dengan cara mencatat atau mendokumentasikan data yang tercantum pada Indonesia Stock Exchange (IDX), www.yahoo.finance.com. Data yang dipergunakan adalah data sekunder. Data sekunder ini diperoleh dari data yang tercantum pada Indonesia Stock Exchange (IDX), www.yahoo.finance.com yang berupa harga saham individual dan harga saham LQ-45 bulanan serta data Sertifikat Bank Indonesia bulanan selama periode 2009-2011.

Analisis pembentukan portofolio yang optimal dapat dilakukan dengan langkah sebagai beikut :

a. Menghitung tingkat pengembalian saham individual :

$$
R_{i t}=\frac{P_{t}-P_{t-1}}{P_{t-1}}
$$

(Jogiyanto; 2003:111)

Keterangan :

$R_{i t}=$ Tingkat pengembalian individual

$P_{t} \quad=$ Harga Investasi sekarang

$P_{t-1}=$ Harga investasi periode lalu

b. Menghitung tingkat pengembalian pasar (dalam penelitian ini IHSG diganti ILQ-45)

$$
R_{m}=\frac{I H S G_{t}-I H S G_{t-1}}{I H S G_{t-1}}
$$

(Jogiyanto; 2003:232)

Keterangan :

$R_{m} \quad=$ Return pasar

$I H S G_{t}=$ Indeks harga saham gabungan periode $\mathrm{t}$

$I H S G_{t-1}=$ Indeks harga saham gabungan sebelum periode $t$

c. Menentukan nilai dasar Beta $(\beta)$ :

$$
\beta=\frac{n\left(\sum X Y\right)-\left(\sum X\right)\left(\sum Y\right)}{n\left(\sum X^{2}\right)-\left(\sum X\right)^{2}}
$$

(Halim, 2005 : 85)

d. Menentukan nilai Alpha $(\alpha)$ :

$$
\begin{aligned}
& Y=a+\beta X \\
& a=Y-\beta X \Longrightarrow \text { rata-rata } \mathrm{Y} \text { atau rata-rata } \mathrm{X}
\end{aligned}
$$

(Halim, 2005 : 85)

e. Varians residual :

$$
\rho_{(A, m)}=\frac{n\left(\sum X Y\right)-\left(\sum X\right)\left(\sum Y\right)}{\sqrt{\left\{n\left(\sum X^{2}\right)-\left(\sum X\right)^{2}\right)\left\{n\left(\sum Y^{2}\right)-\left(\sum Y\right)^{2}\right\}}}
$$

(Halim, $2005:$ 85)

f. Koefisien korelasi :

$$
\rho_{(A, m)}=\frac{n\left(\sum X Y\right)-\left(\sum X\right)\left(\sum Y\right)}{\sqrt{\left\{n\left(\sum X^{2}\right)-\left(\sum X\right)^{2}\right\}\left\{n\left(\sum Y^{2}\right)-\left(\sum Y\right)^{2}\right\}}}
$$

(Halim, 2005 : 85)

g. Excess return to beta ratio. Rasio ini adalah:

$$
E R B_{i}=\frac{E\left(R_{i}\right)-R_{B R}}{\beta_{i}}
$$

(Jogiyanto; 2003:254)

Keterangan : 


$$
\begin{aligned}
E R B_{i}= & \text { excess return to beta sekuritas ke- } \mathrm{i} \\
E\left(R_{i}\right)= & \text { return ekspektasi berdasarkan model } \\
& \text { indeks ganda untuk sekuritas ke- } \mathrm{i} \\
R_{B R}= & \text { return aktiva bebas risiko } \\
& \text { menggunakan sertifikat Bank } \\
& \text { Indonesia (SBI) } \\
\beta_{i} \quad= & \text { Beta sekuritas ke-i }
\end{aligned}
$$

h. Kemudian hitung nilai $\mathrm{Ai}$ dan $\mathrm{Bi}$ untuk masing-masing sekuritas ke-i

sebagai berikut:

$A_{i}=\frac{\left[E\left(R_{i}\right)-R_{B R}\right] \cdot \beta_{i}}{\sigma_{e i}^{2}}$ dan $B_{i}=\frac{\beta_{i}^{2}}{\sigma_{e i}^{2}}$

Notasi : $\sigma_{e i}^{2}=$ varian dari kesalahan residu sekuritas ke-i yang juga merupakan risiko unik atau risiko tidak sistematik.

(Jogiyanto; 2003:254)

i. Hitung nilai $\mathrm{Ci}$ rumusnya sebagai berikut :

$$
C_{i}=\frac{\sum_{i=1}^{n} A_{i} \cdot R_{B R}}{1+R_{B R} \cdot \sum_{i=1}^{n} B_{i}}
$$

(Jogiyanto; 2003:254)

j. Setelah sekuritas yang membentuk portofolio optimal telah dapat ditentukan dicari besarnya proporsi untuk sekuritas ke-i adalah sebesar :

$$
\begin{gathered}
W_{i}=\frac{X_{i}}{\sum_{j=1}^{k} X_{i}} \text { dan, } \\
\text { nilai Xi sebesar : } X_{i}=\frac{\beta_{i}}{\sigma_{e i}^{2}}\left(E R B_{i}-C^{*}\right)
\end{gathered}
$$

(Jogiyanto; 2003:258)

Keterangan :

$$
\begin{array}{ll}
\mathrm{Wi} & =\text { proporsi sekuritas ke- } \mathrm{i} \\
\mathrm{Xi} & =\text { proporsi sekuritas ke-i } \\
\mathrm{K} & =\text { jumlah sekuritas di portofolio optimal }
\end{array}
$$

$\beta_{i} \quad=$ Beta sekuritas ke-i

$\sigma_{e i}^{2}=$ varian dari kesalahan residu sekuritas

ke-i

$\mathrm{ERBi}=$ excess return to Beta sekuritas ke-i

C $^{*} \quad=$ nilai cut off point yang merupakan nilai Ci terbesar.

k. Menentukan return ekspektasi portofolio yang merupakan rata-rata tertimbang dari return-return ekspektasi masing-masing sekuritas tunggal di dalam portofolio :

$E\left(R_{p}\right)=\sum_{i=1}^{n}\left\{W_{i} \cdot E\left(R_{i}\right)\right\}$

(Jogiyanto; 2003:148)

Keterangan :

$E(R p)=$ return ekspektasi dari portofolio

Wi = porsi dari sekuritas $\mathrm{i}$ terhadap seluruh sekuritas di portofolio

$E(R i)=$ return ekspektasi dari sekuritas ke $\mathrm{i}$ $\mathrm{n}=$ jumlah dari sekuritas tunggal.

I. Risiko portofolio :

$\sigma p^{2}=\left(\sum_{i=1}^{n} W i . \beta i\right)^{2} \cdot \sigma_{m}{ }^{2}+\left(\sum_{i=1}^{n} W i . \sigma_{e i}\right)^{2}$

(Jogiyanto; 2003:248)

Keterangan :

$\sigma_{p}^{2}=$ risiko portofolio

$\mathrm{Wi}=$ proporsi sekuritas

$\beta_{i} \quad=$ beta yang mengukur koefisien yang mengukur perubahan $\mathrm{Ri}$ akibat dari perbedaan $\mathrm{Rm}$

$\sigma_{e i}{ }^{2}=$ varian residu

$\sigma_{m}{ }^{2}=$ varian pasar 


\section{HASIL DAN PEMBAHASAN}

\subsection{Hasil Penelitian}

Nilai Ci sebesar -0,0304, yaitu untuk sekuritas AALI dengan nilai ERB sebesar 0.04466 yang merupakan nilai ERB terakhir kali masih lebih besar dari nilai Ci. nilai Ci sebesar -0.4733, yaitu untuk sekuritas ANTM dengan nilai ERB sebesar 0.01466 yang merupakan nilai ERB terakhir kali masih lebih besar dari nilai $\mathrm{Ci}$. nilai $\mathrm{Ci}$ sebesar 0.07998, yaitu untuk sekuritas ASII dengan nilai ERB sebesar 0.04466 yang merupakan nilai ERB terakhir kali masih lebih kecil dari nilai $\mathrm{Ci}$. nilai $\mathrm{Ci}$ sebesar 0.0736, yaitu untuk sekuritas ASRI dengan nilai ERB sebesar 0.01466 yang merupakan nilai ERB terakhir kali masih lebih kecil dari nilai $\mathrm{Ci}$. nilai $\mathrm{Ci}$ sebesar 0.05013, yaitu untuk sekuritas BMRI dengan nilai ERB sebesar 0.02579 yang merupakan nilai ERB terakhir kali masih lebih kecil dari nilai $\mathrm{Ci}$. nilai $\mathrm{Ci}$ sebesar 0.04845, yaitu untuk sekuritas ICBP dengan nilai ERB sebesar 0.04315yang merupakan nilai ERB terakhir kali masih lebih kecil dari nilai Ci. nilai Ci sebesar 0.04817, yaitu untuk sekuritas IMAS dengan nilai ERB sebesar 0.5853yang merupakan nilai ERB terakhir kali masih lebih kecil dari nilai $\mathrm{Ci}$.

Sekuritas-sekuritas yang mempunyai nilai ERB lebih besar dari Ci sekuritas ini dimasukan sebagai bagian dari portofolio optimal, oleh karena itu sekuritas dengan perusahaan Astra Argo Lestari,Tbk (AALI) dan Aneka Tambang, Tbk (ANTM) dimasukan sebagai bagian dari portofolio optimal. Setelah sekuritas tersebut membentuk portofolio yang optimal telah dapat ditentukan, berapa besar porsi masing-masing sekuritas tersebut di dalam portofolio optimal

Nilai Wi yang merupakan proporsi sekuritas, berdasarkan hasil perhitungan maka proporsi untuk perusahaan Astra Argo Lestari,Tbk (AALI) sebesar 67,3065\% dan Aneka Tambang, Tbk (ANTM) sebesar 32,6935\%

Hasil dari ekspektasi portofolio yang merupakan rata-rata tertimbang dari returnreturn ekspektasi masing-masing sekuritas tunggal di dalam portofolio sebesar 0.022903 sedangkan untuk hasil risiko sebesar 0.001405. Artinya apabila, return yang diharapkan sebesar 0.022903 maka akan menghasilkan risiko 0,001405

\subsection{Pembahasan}

Rata-rata harga saham index LQ-45 mengalami peningkatan dari tahun 2009 yang semula sebesar Rp. 498.288 naik di tahun 2010 sebesar Rp. 585.447 kemudian naik kembali pada tahun 2011 menjadi sebesar Rp 663.223. Ini berarti bahwa rata-rata harga saham index LQ-45 cenderung meningkat dari tahun ke tahunnya.

Rata-rata harga saham perusahaan dengan kode AALI mengalami peningkatan tahun 2010 sebesar Rp. 22.429, dari tahun 2009 sebesar Rp 18.071. Kemudian terjadi sedikit penurunan tahun 2011 sebesar Rp. 22.196 dari tahun 2010 sebesar Rp. 22.429. rata-rata harga saham perusahaan dengan kode ANTM mengalami peningkatan tahun 2010 sebesar Rp. 2.241, dari tahun 2009 sebesar Rp 1.870, sedangkan terjadi penurunan tahun 2011 sebesar Rp. 2.241 dari tahun 2010 sebesar Rp. 1.967. Rata-rata harga saham perusahaan dengan kode ASII mengalami peningkatan dari tahun 2009 sebesar Rp . 2.422 ke tahun 2010 menjadi sebesar Rp. 4.760 dan naik kembali tahun 2011 sebesar Rp 6.255.

Rata-rata harga saham perusahaan dengan kode ASRI mengalami peningkatan masingmasing tahun 2009 sebesar Rp 92, tahun 2010 sebesar Rp. 200, dan tahun 2011 sebesar Rp 357. Rata-rata harga saham perusahaan dengan kode BMRI mengalami peningkatan masing-masing tahun 2009 sebesar Rp 3,455, tahun 2010 sebesar Rp. 5,888, dan tahun 2011 sebesar Rp 6,783 .

Return pasar yang dilihat dari return Index LQ 45 mengalami penurunan dari tahun 20092011. Penurunan sebesar 0.0252 (dalam satuan rasio) di tahun 2010 dari tahun sebelumnya sebesar 0.0552 (dalam satuan rasio) di tahun 2009 atau penurunan sebesar 0.0032 (dalam satuan rasio) di tahun 2011 dari tahun 
sebelumnya sebesar 0.0252 (dalam satuan rasio) di tahun 2010. Return saham perusahaan kecuali perusahaan dengan kode ASRI, mengalami penurunan yang sangat signifikan di antaranya perusahaan dengan kode AALI, ANTM, BMRI, ICBP, IMAS.

Kenaikan rata-rata harga saham ataupun return pasar serta return saham perusahaan pada tahun tertentu (2009-2011) menunjukan bahwa perusahaan secara individual tidak terlalu terpengaruh kondisi global seperti krisis keuangan Eropa yang terjadi pada tahun 2011 dan transisi krisis keuangan global ataupun pengaruh lainnya. Lain halnya dengan yang terjadi pada return pasar indeks LQ-45 yang turut mengalami penurunan.

Nilai $(\beta)$ tertinggi dimiliki oleh perusahaan dengan kode BMRI sebesar 1,5464 (dalam satuan rasio) yang berarti return saham perusahaan ini akan meningkat 1,5464 \% bila return pasar naik 1 $\%$ atau sebaliknya. Adapaun nilai $(\beta)$ terendah dimiliki oleh perusahaan dengan kode IMAS sebesar -0,4372 (dalam satuan rasio) yang berarti return saham perusahaan ini akan turun sebesar 0,4372 \% bila return pasar naik $1 \%$.

Perusahaan yang memiliki nilai $(\beta)$ tinggi menunjukan bahwa sekuritas tersebut mempunyai $(\beta)$ yang lebih besar dibandingkan $(\beta)$ rata-rata industrinya, sebaliknya perusahaan yang memiliki nilai $(\beta)$ rendah menunjukan bahwa sekuritas tersebut mempunyai $(\beta)$ yang lebih kecil dibandingkan ( $\beta$ ) rata-rata industrinya. Nilai beta agresif terjadi pada perusahaan dengan kode ANTM, ASII, ASRI BMRI. Dikatakan nilai beta agresif karena nilai beta lebih besar dari satu artinya saham tersebut mempunyai kepekaan yang tinggi terhadap kondisi pasar. Saham-saham yang agresif sangat berisiko terhadap kondisi pasar yang lesu (bearish) dan akan memperoleh laba atau keuntungan yang besar pada saat pasar naik (bullish). Nilai beta defensif terjadi pada perusahaan dengan kode IMAS. Dikatakan nilai beta defensif karena nilai beta lebih kecil dari satu, artinya saham tersebut kurang peka terhadap perubahan kondisi pasar.
Nilai alpha hanya berhubungan dengan peristiwa mikro (micro event) yang mempengaruhi perusahaan tertentu saja, tetapi tidak mempengaruhi semua perusahaan secara umum, jadi dalam hal ini alpha hanya menunjukan suatu variabel acak yang menunjukan komponen dari suatu sekuritas yang independen terhadap kinerja pasar.

Risiko saham yang tinggi adalah IMAS sebesar 0,91142 sedangkan risiko saham yang rendah adalah AALI sebesar 0.006958. Artinya, bagi para investor risk seeker bisa menanamkan modalnya secara individual di saham perusahaan Indomobil Sukses International (IMAS) sedangkan untuk para investor risk averse dapat menanamkan modalnya pada perusahaan Astra Argo Lestari (AALI).

Nilai Ci sebesar -0,0304, yaitu untuk sekuritas AALI dengan nilai ERB sebesar 0.04466 yang merupakan nilai ERB terakhir kali masih lebih besar dari nilai Ci. Kemudian nilai Ci sebesar -0.4733, yaitu untuk sekuritas ANTM dengan nilai ERB sebesar 0.01466 yang merupakan nilai ERB terakhir kali masih lebih besar dari nilai Ci. Nilai Ci sebesar 0.07998, yaitu untuk sekuritas ASII dengan nilai ERB sebesar 0.04466 yang merupakan nilai ERB terakhir kali masih lebih kecil dari nilai $\mathrm{Ci}$. Nilai $\mathrm{Ci}$ sebesar 0.0736, yaitu untuk sekuritas ASRI dengan nilai ERB sebesar 0.01466 yang merupakan nilai ERB terakhir kali masih lebih kecil dari nilai Ci. Nilai Ci sebesar 0.05013, yaitu untuk sekuritas BMRI dengan nilai ERB sebesar 0.02579 yang merupakan nilai ERB terakhir kali masih lebih kecil dari nilai Ci. Nilai $\mathrm{Ci}$ sebesar 0.04845, yaitu untuk sekuritas ICBP dengan nilai ERB sebesar 0.04315 yang merupakan nilai ERB terakhir kali masih lebih kecil dari nilai Ci. Nilai Ci sebesar 0.04817, yaitu untuk sekuritas IMAS dengan nilai ERB sebesar 0.5853 yang merupakan nilai ERB terakhir kali masih lebih kecil dari nilai Ci.

Sekuritas-sekuritas yang mempunyai nilai ERB lebih besar dari Ci sekuritas ini dimasukan sebagai bagian dari portofolio optimal. Oleh karena itu sekuritas dengan perusahaan Astra 
Argo Lestari,Tbk (AALI) dan Aneka Tambang, Tbk (ANTM) dimasukan sebagai bagian dari portofolio optimal. Nilai Wi yang merupakan proporsi sekuritas, berdasarkan hasil perhitungan maka proporsi untuk perusahaan Astra Argo Lestari,Tbk (AALI) sebesar 67,3065\% dan Aneka Tambang, Tbk (ANTM) sebesar 32,6935\%. Hasil dari return ekspektasi portofolio yang merupakan rata-rata tertimbang dari returnreturn ekspektasi masing-masing sekuritas tunggal di dalam portofolio sebesar 0.022903 sedangkan untuk hasil risiko sebesar 0.001405 . Artinya dengan return yang diharapkan sebesar 0.022903 maka portofolio ini menimbulkan risiko 0,001405 .

Permasalahan dari praktek investor saham kurangnya memahami akan masalah risiko dari transaksi investasi saham mereka. Konsep/model optimasi portofolio memberikan kaidah yang mana pertimbangan dalam berinvestasi dapat mengurangi risiko investasi apabila investor membeli saham tidak secara individual, namun harus didiversifikasi.

Dengan menggunakan Single Index Model diperoleh hasil portofolio optimal dan perusahaan yang termasuk kedalam portofolio optimal adalah perusahaan Astra Argo Lestari,Tbk (AALI) dan Aneka Tambang, Tbk (ANTM). Terbukti bahwa dengan diversifikasi dapat menurunkan risiko daripada risiko saham individual. Apabila kita membelanjakan uang kita $100 \%$ hanya pada saham AALI, maka risiko yang akan kita tanggung adalah 0.006958 atau 100\% dibelikan seluruhnya untuk saham ANTM, maka risiko yang harus ditanggung adalah sebesar 0.020194. namun apabila kedua saham tersebut didiversifikasikan dalam satu portofolio investasi, maka risikonya akan turun menjadi 0.001405 .

Tentu saja pendiversifikasian dua saham ini, memberikan return ekspektasian portofolio yang lebih rendah yaitu sebesar 0.022903 dari return ekspektasian saham AALI sebesar 0.02564, namun tidak lebih rendah dari return ekspektasian saham ANTM sebesar 0.01727. Hal ini terjadi karena return ekspektasian portofolio merupakan rata-rata tertimbang dari returnreturn saham pembentuknya dan demikian pula bahwa risiko portofolio adalah rata-rata tertimbang dari risiko-risiko saham pembentuknya.

Adapun mengapa dalam model indeks tunggal ini pemilihan saham yang akan dimasukkan ke dalam set portofolio didasarkan pada ERB yang lebih besar dari Ci dikarenakan ERB menunjukkan tingkat premi risiko yang paling tinggi. Artinya secara rasional, ketika investor dihadapkan kepada suatu nilai risiko yang bersedia dia tanggung, maka akan memilih imbal hasil yang paling tinggi dari pilihan sekian banyak portofolio. Pada model ini, premi risiko tertinggi diwakili oleh nilai ERB yang paling tinggi pula.

Perhitungan ERB ini sekaligus merupakan keunggulan dari segi praktis lain dari metode model indeks tunggal karena memberikan kesempatan investor untuk membuang sahamsaham yang tidak layak untuk masuk dalam portofolio optimalnya sebelum dilakukan perhitungan optimalisasi dengan menentukan porsi dari masing-masing saham terpilih. Dalam penelitian ini, ada 5 saham yang tidak diikut sertakan dalam portofolio karena memberikan nilai ERB atau premi risiko yang rendah bagi investor sehingga hanya saham AALI dan ANTM saja yang dipilih.

Artinya, model indeks tunggal masih konsisten dengan tujuan-tujuan diversifikasi dan pembentukan portofolio investasi secara umum dan yang lebih penting adalah secara praktis model ini cukup baik digunakan untuk melakukan pembentukan portofolio di pasar Indonesia khususnya di Bursa Efek Indonesia (BEI). Pembentukan portofolio dengan menggunakan single index model dapat dijadikan dasar untuk menentukan investasi mana yang akan dipilih, penelitian-penelitian terdahulu seperti yang dilakukan oleh Noki Rachmanto (2002), Sukarno (2007), Robi (2008), Viola Claudia (2011), Arif dan Didin (2011), dan penelitian ini ada suatu sudut pandang yang sama. Pertama, 
mendasarkan diri pada pemikiran bahwa tingkat keuntungan suatu sekuritas dipengaruhi oleh tingkat keuntungan portofolio pasar.

Dengan menggunakan model indeks tunggal bisa direduksi jumlah variabel yang perlu ditaksir, karena tidak perlu lagi ditaksir koefisien korelasi untuk menaksir deviasi standar portofolio. Kedua, memberikan pemahaman bahwa tingkat preferensi investor saham terhadap imbal hasil maupun risiko, investasi dilihat dari tingkat optimasi dan efisiensi dari transaksi suatu investasi saham. Artinya untuk melihat imbal hasil maupun tingkat risiko harus kepada konsep dari trade off antara dua aspek tak terpisahkan dari investasi tersebut.

Saham yang imbal hasilnya paling tinggi pada tingkat risiko tertentu atau yang risikonya paling rendah pada tingkat imbal hasil tertentulah yang dapat dikatakan optimal. Jadi, investor untuk melakukan diversifikasi dalam keputusan investasi saham mereka agar dapat saling menutupi antara variasi imbal hasil dan risiko satu saham dengan saham lainnya sehingga diharapkan pencapaian investasi optimal para investor dapat tercapai.

\section{KESIMPULAN}

Berdasarkan hasil analisis data dan pembahasan yang telah dijelaskan pada Bab terdahulu, maka dapat ditarik kesimpulan dari penelitian ini sebagai berikut :

1. Dengan menggunakan Single Index Model diperoleh hasil portofolio optimal dan perusahaan yang termasuk kedalam portofolio optimal dalah perusahaan Astra Argo Lestari,Tbk (AALI) dan Aneka Tambang, Tbk (ANTM).

2. Terbukti bahwa dengan diversifikasi dapat menurunkan risiko daripada risiko saham individual

\section{REKOMENDASI}

1. Bagi investor yang akan menanamkan investasinya pada perusahaan kelompok LQ45 di BEl sebaiknya harus benar-benar teliti dalam menganalisa saham guna memperoleh informasi yang akurat baik return, risiko, dan kemungkinan lain yang melekat pada saham di mana ia berinvestasi, sehingga nantinya diharapkan investor akan mendapatkan keuntungan sesuai dengan yang diharapkan. Dan menggunakan analisis yang tepat, dapat dilakukan dengan analisis single Index Model, berdasarkan hasil analisis tersebut investor dapat menanamkan modalnya pada perusahaan Argo Lestari,Tbk (AALI) dan Aneka Tambang, Tbk (ANTM) dengan proporsi untuk perusahaan Astra Argo Lestari,Tbk (AALI) sebesar 67,3065\% dan perusahnaa Aneka Tambang, Tbk (ANTM) sebesar 32,6935\%

2. Peneliti menyadari bahwa penelitian ini masih jauh dari sempurna, untuk itu peneliti memberikan saran untuk penelitian selanjutnya, sebaiknya periode penelitian yang digunakan ditambah sehingga menghasilkan informasi yang lebih mendukung, jumlah sampel yang digunakan dapat ditambah dan dapat diperluas ke beberapa sektor perusahaan, lalu perbandingan dengan analisis optimalisasi lain., sehingga nantinya diharapkan kesimpulan yang diperoleh lebih sempurna. Keterbatasan penelitian ini adalah tidak mengambil seluruh saham yang termasuk pada kelompok saham LQ-45 namun dilakukan pemilihan saham terbaik dari masing-masing sektor industri yang diwakilinya.

\section{DAFTAR PUSTAKA}

Abdul Halim. (2005). Analisis Investasi. Edisi ke-2. Jakarta : Salemba Empat.

Arif dan Didin. (2011). Pembentukan portofolio optimal saham dengan model indeks 
tunggal pada saham-saham perbankan di Bursa Efek Indonesia tahun 2011. Jurnal Manajemen Universitas Gunadarma. Volume : 1. Halaman : 22-30.

Jogiyanto. (2003). Teori Portofolio dan Analisis Investasi; Edisi ketiga. Yogyakarta : BPFE.

Jogiyanto. (2010). Teori Portofolio dan Analisis Investasi; Edisi ketujuh. Yogyakarta : BPFE.

Noki Rachmanto. (2002). Analisis Pembentukan Portofolio Optimal Saham di BEJ dengan Model Index Tunggal. Tesis Universitas Dipenogoro. Semarang

Robi. (2008). Analisis Portofolio Optimal Sahamsaham LQ-45 pada Periode Agustus 2005 Juli 2006 dengan Metode Single Index Model di Bursa Efek Jakarta. Business \& Management Journal Bunda Mulia. Vol: 4, No.1. Halaman : 2-22.

Sukarno. (2007). Analisis Pembentukan Portofolio Saham Menggunakan Single Indeks di Bursa Efek Jakarta. Tesis Universitas Dipenogoro. Semarang

Viola Claudia. (2011). Analisis Portofolio Optimal Investasi Saham yang Tercatat Sebagai Indeks LQ-45 pada Bursa Efek Indonesia dengan Model Indeks Tunggal (Periode 2009-2011). Tesis Universitas Gunadarma. Jakarta.

Zalmi Zubir. (2011). Manajemen Portofolio : Penerapannya dalam Investasi Saham. Jakarta : Salemba Empat.

Website :

http://yahoo.finance.com

http://bapepam.go.id

http://www.bukumarketiva.we.id 